\title{
인도네시아 원조공여국 회의(CGI) 개최
}

\section{1. 회의개요}

- 표제회의가 인도네시아 정부주관(WB 인니 사무소 협조)으로 "경제·사회개발, 재난대 응 및 2006년 원조국 유무상 원조”를 주요 토의의제로 6.14 (수) 인도네시아 중앙은행에 서 원조 공여국 정부대표(21개국 참가), World Bank, UNDP, IFC, IMF, ADB, 이 슬람 개발은행(IDB) 등 9 개 국제기구, NGO 대표 등이 참석하여 개최된 바, 주요 내용을 아래와 같이 보고함.

\section{2. 핵심요지}

- Boediono 경제조정장관은 개막사를 통해 금년도 5.7-5.9\%대의 경제성장을 위해서 개혁 프로그램(투자, 기간산업 정책 패키 지 발표 및 금융정책 패키지 준비중)과 주 재국 경제 현황을 설명하고 5.27 발생한
족자카르타 지진피해 관련 복구에 긴급 지원을 한 CGI 멤버들에 대한 사의를 표함.

- 금번 회의에 참석한 미국, 일본, $\mathrm{EU}$, 한국 등 주요 국가대표들 및 국제기구 대표들은 최근 인니 정부에 의한 경제 개혁 노력을 평 가하고, 향후 지속적인 경제성장, 빈곤퇴치 및 외국인투자유치를 위해서는 투자여건 개 선 및 개혁정책의 실질적인 이행이 선행되어 야 함을 강조함.

- 금번 CGI 회의시, CGI 멤버들은 39억불 의 개발차관 및 2 억불 규모 무상원조를 발표

- 별도로 15 억불 규모의 족자카르타 및 중 부자바 지진피해 지원 의사를 밝힘.

- 우리 대표는 금년도 $\mathrm{EDCF} 1$ 억불 및 무상 원조 14.19 백만불(족자 지진피해 지원 2 백만불 포함) 지원 의사를 발표함. 


\section{3. 주요 내용}

\section{가. 의제 $1:$ 경제 (투자, 성장 및 거시경제) 및 사회개발}

- Mulyani 재무부 장관은 금년도 5.7 5.9\% 의 경제성장(당초 정부목표 $6.2 \%$ 의 하향조 정) 및 내년도 6 6.5\%의 성장달성을 위한 안정적인 거시경제 정책의 운영 및 외국인 투자확대를 위한 신투자법 및 관세, 세제 등 세법개정, 인프라 확충을 위한 인니 정부의 지원정책 소개 및 이의 충실한 이행을 약속 하면서 CGI 국가들에 대한 지속적인 개발원 조 및 투자증대를 요청함.

- 동 재무장관은 대인니 기간산업 투자관련 "리스크 분산 재정지원 장관령(financial risk resharging decree)"을 최근 서명하 였다고 소개함

※ 금번 회의시 인니 정부가 발표한 2006 년도 주요 거시경제 전망치

- GDP 성장률 : 5.7-5.9\%

- 재정적자율 : GDP 대비 1.3-1.5\%

- 루피화 환율 : 미달러화대비 9300Rp

- 이자율 : $12 \%$

- 인플레율 : $8 \%$

- Abdullah 중앙은행장은 루피화 가치 안정 및 $15 \%$ 대의 높은 인플레이션을 억제하기 위 해, 현재 고이자율 정책(현재 $12.5 \%$ ) 및 긴축 적인 통화정책(Tight Monetary Policy)을 활용하고 있음을 설명하고 금융부문의 개혁
을 금년 하반기에 경기가 회복될 경우 금년 도 연평균 $5.7 \sim 5.9 \%$ 대의 경제성장이 가능 할 것이라고 예측함.

- 2006년도 $1 / 4$ 분기 성장률 $4.6 \%$ 였으며, $\mathrm{IMF}$ 측은 금년도 성장률을 $5.2 \%$ 대로 전 망함.

- Boediono 경제조정장관은 빈곤퇴치 및 경 제성장이 인니 정부의 최우선 정책과제이며, 저소득층을 위한 교육예산 확대, 인적자원 개발을 위한 프로그램개발 및 사회약자 보호 프로그램 도입을 통해 경제성장의 과실이 직 접 빈곤퇴치로 이어질 수 있도록 하는 전달 체계의 개선을 약속함.

- 05.10.1 단행된 국내유가인상(평균 $126 \%$ 인상) 관련, 저소득층을 상대로 한 현금 지 원 프로그램이 성공적이었다고 언급함.

- Widodo 정치 · 법률 - 안보조정장관은 최근 인니 정부의 부패척결을 위한 지속적인 노력 을 설명하고 테러리즘 등 국가안보, 불법도 벌, 밀수, 불법조업 근절 문제 등이 인니 정 부의 주요 관심사라고 소개함.

- 이에 대해 CGI 멤버들은 금년 하반기에도 정부 예측과는 다르게 경제성장 둔화의 지속 가능성에 대한 우려의 표시와 함께 경제성장 을 위한 선정 강화(good governance), 경제 개혁조치의 실질적인 이행 및 관련 개혁 법 안의 조속 의회 통과 등 부패척결을 위한 지 속적인 개혁프로그램을 요청함.

- 한국정부로서도 주재국이 추진중인 개혁 
프로그램을 제대로 이행하는 것이 가장 중 요하며 우리의 과거 개발경험을 바탕으로 주재국에 개발과정에 기여할 의사가 있음 을 설명함. 한편, 노동집약적 산업에 집중 투자하고 있는 한국기업들의 투자 확대를 위해서는 노동법 개정이 신속하게 이루어 져야 함을 강조함.

- 이에 대해 Boediono 경제조정장관도 현 재 노동자단체와 사용자 단체간 노동관계 전반에 대한 협상이 진행중인 바, 동 협상 추이를 보아 가면서 노동법 개정 문제를 검토해 나갈 예정이라고 답변함.

\section{나. 의제 2 : 재난대응(족자카르타 지진, 조류독 감 및 아체 쓰나미)}

- 인니 정부는 금번 족자카르타 지진 및 2004 년 남아시아 지진피해에 대한 CGI 회원국들 의 신속하고 관대한 지원에 감사의 뜻을 전 하고, 금번 족자카르타 및 중부 자바지역의 “지진피해 및 손실 산정 보고서”(지진피해규 모를 31억불로 잠정 추산, 별첨1 참조)를 제 출함. 조만간 이를 바탕으로 재건·복구 Action Plan을 만들 예정이나, 족자카르타 의 경우 아체와는 다르게 지방 정부가 건재 하고 피해 분야도 주로 주택 파손에 집중되 어 있음을 고려, 신속한 재건·복구 추진이 필요함을 강조함.

- 주재국 정부는 자체 예산으로 7.1부터 피 해 지역에서 주택 수리 및 재건 파일럿트
프로젝트를 개시할 예정이라 하며, 공여국 들에 대해 이에 동참해 줄 것을 요청함.

- World Bank는 금융지원을 위한 각국의 지 원약속도 중요하지만 실제 지원금액이 부문 별로 mis-matching되는 비효율적 배분을 막기 위해 재원배분 의 효율적인 mechanism 구축이 선행되어야 함과 동시 에 Aceh지역의 peace process를 위한 모니 터링 체계 확보도 필요함을 언급함.

- 주요 국가들의 족자르타 및 중부자바 지진 피해 관련 지원 규모 발표

- 일본(1천만불), 미국(7백만불), 영국(500만 파운드), 호주(750만 호주불), $\mathrm{EU}(3$ 백만 불) 등

- 우리 대표단도 19 명의 긴급구호팀 파견 및 2 백만불의 긴급구호 및 재건 - 복구 자금 지원을 설명하고 조속한 피해복구 과정에 적극 참여하겠다고 언급함.

\section{다. 의제 $3: 2006$ 년도 재정소요 및 2007년도 연간 작업계획}

- 인니 정부는 2006년도 재정소요 및 중기개 발계획(2004 2009년)에 따라 2007년도 주요 추진과제(9개)가 담긴 연간 작업계획 을 발표하고, 빈곤퇴치, MDGs 달성, 고용 확대 및 수출·투자 확대를 통한 안정적인 경제성장을 위해서 부족한 재정소요 부문은 국채발행 및 외화차입을 통할 수 밖에 없다 고 설명하면서 이를 위해 무엇보다도 CGI 
회원국들의 적극적인 유무상원조를 기대한 다고 언급함.

- 2006년도 재정 소요 규모

: 총 167 170억불

- 예산적자 : 43 46억불

- 외채상환 등 기타 소요 : 123 억불

- 2006년도 재정 소요분 조달 계획

: 167 170억불

- 국내조달(국채발행등) : 120 123억불

- 해외조달 : CGI 39 42억불, non-CGI 4 5억불

- 이에 대해 CGI 회원국들은 유무상포함 총 54 억불을 중기 경제개발 및 재건복구에 지 원하기로 약속하고, 이중 39억불은 2006년 도 개발지원자금으로 서약하고, 족자카르타 지진 피해 복구 자금지원으로 15 억불을 발 표함.

- 39 억불의 개발지원 자금을 37 억불의 프로 그램 및 프로젝트 loan이고 나머지 2억불 은 정부개혁프로그램을 지원하는 무상 (grants)으로 지원할 예정

- 주요 국가의 지원액 규모 : World Bank 9-11억불, $\mathrm{ADB}$ 9억불, 일본 8.4억불, 독 일 2.5 억불, 영국 5 천만파운드, 호주 3.2 억호주불, 미국 1.7 억불(추가로 55 만불 지 원예정) 등

- 우리 대표단은 인니를 금년부터 중점 지원 대상국으로 선정하였다고 소개하고 2006 2009년까지 우리의 대인니 유무상지원
금액은 4.3억불(4억불 $\mathrm{EDCF}$ 차관, 3천만 불 무상원조)규모이며, 2006년도에는 1억 불의 유상 및 1,419 백만불의 무상지원(2백 만불 족자카르타 지진피해 복구내용 포함) 을 발표함.

\section{4. 족자카르타 및 중부자바 지진 피해 재건 - 복구 지원 방법}

- 주재국 Boediono 경제조정장관 및 Sri Mulyani 재무장관에 따르면 주재국측은 금 번 족자카르타 및 중부자바 지역 지진 피해 시 재건 · 복구를 위한 공여국들의 지원 절차 에 대해 아래 방법을 제시함.

(1) 아체 경우처럼, World Bank 주관으로 다 국가 신탁기금(Multi-donor Trust Fund)을 설치하고 각국이 동 기금에 지 원금을 납부하는 방안

- 단, 이 경우 별도의 신탁기금 설치 대 신, 기존 아체 신탁기금 메카니즘을 활 용하는 방안 검토중

- 동 기금에 공여국이 재건 - 복구비용을 납부할 경우, World Bank 가 인니 정 부 및 기금 납부 공여국들과 협의, 재 건 · 복구 프로그램을 마련하고, 공동 이행하는 방식(Pool 방식)

(2) 각 공여국이 재건 - 복구비용을 인니 정부 예산에 제공하는 방법(인니 정부가 선호 하는 방식) 
- 이 경우, 인니 정부가 자체 재건 - 복구 프로그램에 지원금을 사용하고 공여국 에 대해서 사용 결과를 통보해 주는 방식

- 재무장관에 따르면 무상지원의 경우, 각 공여국이 직접 족자카르타 지방 정 부에 대해 기금을 제공해도 무방하다는 입장

(3) 각 공여국이 재건 - 복구 사업을 자체적으 로 마련하여, 직접 지원금을 집행하는 방식

- 이 경우, 지방 정부와 협의, 적절한 재 건 · 복구 사업을 발굴해서 공여국이 직 접 계약, 사업 추진 방식
- 상기 방식 관련 우리 정부는 기존 아체 관례 에 따라 3 번째 방식(직접지원방식)을 채택하 는 것이 바람직 할 것으로 판단되나, 본부 검 토 결과를 회신 바람.

- 단, 지원대상 사업 분야는 주재국 정부 의 재건 · 복구 Action Plan 작성 및 여 타국의 지원 동향 등을 보아 가면서 추 후 건의 예정 ※ 족자카르타 주지사(술탄)는 한국 정 부가 건축자재(벽돌, 기와, 나무, 시 멘트 등)를 지원해 줄 것을 요청한 바 있음. 